Emotional and emotive language: modal particles and tags in unified Berlin

\author{
Natalie Braber ${ }^{1}$ \\ School of Languages, Linguistics and Cultures \\ University of Manchester \\ Oxford Road \\ Manchester \\ M13 9PL \\ United Kingdom
}

Email: natalie.braber@ntu.ac.uk

${ }^{1}$ Present Address: Dr Natalie Braber, School of Arts, Communication and Culture, Nottingham Trent University, Clifton, Nottingham, NG11 8NS, United Kingdom. Telephone: 00441158483011 


\title{
Emotional and emotive language: modal particles and tags in unified Berlin
}

\begin{abstract}
:
This paper endeavours to show the relationship between emotion and language, in particular with respect to the use of modal particles in German. Modal particles have long been considered insignificant fillers without a specific function and as such, not worthy of linguistic investigation. This is clearly a view which cannot be sustained. Modal particles have been found to illustrate the speaker's opinion of what is being said; in addition, they may add emphasis. Certain German modal particles (especially halt and eben) are examined as they occur in a corpus of utterances containing accounts of highly emotional events, related to East and West Berliners' experiences after the fall of the Berlin Wall and German unification. By reviewing spoken accounts of events which were life-changing for one side, but only nominal for the other, thereby producing different emotions, the article demonstrates the use of these modal particles. The analysis suggests that there is a direct link between emotion and the way these speakers of German use their language. .
\end{abstract}

Key words: Modal particles; tags: emotion; German unification; Berlin Wall; German; halt; eben

\section{Biographical Note}

Natalie Braber completed her M.A. Hons. and Ph.D. at the University of St. Andrews in Scotland. After a post-doctoral position in the Department of Psychology, and a lectureship in the Department of English Language and Linguistics at the University of Manchester, she now lectures in the School of Arts, Communication and Culture at Nottingham Trent University. 


\section{Emotional and emotive language: modal particles and tags in unified Berlin}

\section{INTRODUCTION}

The relationship between emotion and language remains a relatively uncharted territory within the study of language and linguistics. In this field, modal particles and tags have been somewhat neglected. This article presents a case study of the use of modal particles and tags in Berlin following German unification in 1989.

Concentrating on the use of two modal particles and tag questions, the article illustrates how these expressions are used in spoken German and how they can be intended to manifest, as well as arouse, feelings. In analysing the usage of modal particles (especially halt and eben) and tags, this study aims to shed new light on the relations between emotion and language in general.

The fall of the Berlin Wall in 1989 and the subsequent demise of the East German government (which will sometimes be referred to as the Wende in this article) heralded the unification of Germany after 44 years separation, following the end of the Second World War, with two German states in existence for over 40 years. For the citizens of the former German Democratic Republic in the East, unification meant huge changes, affecting nearly all aspects of life, including housing, employment and political beliefs. For the citizens of the German Federal Republic in the West (which now incorporated the former East German state), unification had different consequences. These included increased taxation to pay for shortages in the east and, especially important for those living in West Berlin, the ability to travel in the East. As Patrick Stevenson has shown, unification resulted in complex changes, affecting particularly the East Germans, who had to adapt to a completely new way of living (Stevenson, 2002:115). Even today, there are still many deep-seated differences between East and West Germans. These differences are not only linguistic, but also social, economic and cultural in character.

Whereas languages such as English do not appear to use modal particles, many other languages, including German, use such particles frequently in spoken language. Rather than using modal particles, English avails itself of intonation, tag questions (such as isn't it and don't you think?) and sentence adverbials (especially attitude markers such as surely, frankly, of course) to provide subjective nuances. Traditionally, modal particles tended to be disregarded in the study of language as having no meaning. Baerentzen has argued that modal particles were treated as if they had no function (Baerentzen 1989:19). Linguists could not agree in which word class, if any, modal particles belonged. Often, modal particles were not described as having a specific function and were grouped under the heading of other word classes such as prepositions, adverbs and conjunctions, since these, too, were uninflected. Historically, this negative attitude towards modal particles is further reflected in the names modal particles were given in a language such as German: Fügewörter ('plug words'), Sprachhülsen ('language shells'), unscheinbare Kleinwörte ('insignificant small words'), sinnlose Einschiebseln ('meaningless insertions'), Parasiten ('parasites') and Läuse im Pelz der Sprache ('lice in the fur of language'). In the dictionaries, too, modal particles were not sufficiently well explained and this led to them being considered less important when it came to language teaching. 
However, as newer research has established, modal particles play important roles, especially in spoken language. For example, although originally thought of as nothing more than 'fillers', modal particles can clearly be distinguished from genuine fillers such as $a h$ in English and $\mathrm{hm}$ in German, inasmuch as the former are subject to various contextual restrictions and therefore must be considered integral parts of sentence structure. Linguists such as Helbig have realised that although these words are uninflected, they cannot be grouped together with other types of uninflected words, as they behave differently (Helbig 1988:11).

Modal particles are used frequently in spoken language, even though they apparently not are absolutely necessary; hence these words must have some function. Moreover, even in spoken language there is a different distribution of modal particles: they are more common in spontaneous than in planned speech, appearing more in informal than in formal registers, and more in dialogue than in monologue. Modal particles do not refer to any particular word in the sentence, but to the sentence as a whole, thereby changing its nuance.

The exact nature of these particles' functions thus remains elusive, even though some research has been carried out examining the precise nature of their appearance in language (Molnár 1998, 2003). Bublitz writes that an exact description of the role modal particles play in language has not yet been achieved; they are different from other lexemes as they cannot be described outside the context of the sentence they appear in (Bublitz 1978:10). Hartog and Ruttenauer (1982:70) argue that modal particles are difficult to describe without comparing them to other modal particles. One must be able to paraphrase the modal particles; according to Burkhardt, those linguists who do not think that modal particles can be paraphrased do not fully understand the semantic status of these words; by removing modal particles from sentences, one can isolate their full semantic content (Burkhardt 1982a:88). Linguists now agree that modal particles express the subjective opinion of a speaker about the propositional content of a sentence; thus, Burkhardt writes that their function is dialogue control (Burkhardt 1982b:153), while König adds that modal particles can facilitate inferencemaking in conversation (König 1997: 62). Modal particles cannot affect a sentence's truth value, but they can alter the sentence semantically and pragmatically (Helbig 1995:9; Karagjosova 2003:335). Context is crucial, as meanings can change in different sentences and therefore every occurrence has to be interpreted individually.

According to Heringer, the emotional aspect of modal particle use is still neglected in research (Heringer 1988:738). He writes here that although modal particles somehow seem to be connected to emotion, this connection has rarely been scrutinised. Still, researchers have found that in a context of oral communication, modal particles are expected by the listener (Weydt 1969:20). If they are not used, the conversation seems unfriendly and can appear impersonal. Modal particles can be used to express what the speaker feels and help to bring what is being felt to the attention of those listening. Most speakers are not aware that they are using modal particles, just as they are often not aware of their facial expressions or body language while speaking. As Helbig points out, modal particles can be used to imply that which is not said (Helbig 1988:12-3).

From Sigmund Freud to William James and Nico Frijda, psychologists have studied emotion, including the expression and suppression of feelings (e.g. James, 1967; Frijda, 1987). These phenomena relate closely to the usage of language proper as well as to its non-verbal equivalents, and show how people share their feelings with 
others. People rarely interact without some aspect of feeling; what they say, how they say it, and what they do not say may convey the emotional state of a person. Yet the effect of emotion upon language remains often neglected in academic studies.

When people grow up in a particular culture, they learn to adapt or modify their language in order to show their feelings to others. This is crucial for continued understanding within a social group. Bloom and Beckwith claim: "Language is the preeminent mode of expression and is provided by society and culture for making manifest and public that which is internal to the individual” (Bloom and Beckwith 1989:337). Nevertheless, the relations between emotion and language are rarely analysed. Research has tended to focus in a limited way on how emotion can condition language, but usually not on how language can condition emotions (Caffi 1994:246).

This paper examines the emotional involvement of speakers in the propositional content of their utterances. To this end, it compares the use of modal particles and tags by two groups of people, one of them talking about a subject that is very emotional to them, the other talking about the same subject, but feeling less strongly about it. The aim of this comparison is to shed new light on the functions of modal particles and tags, and thus to add to our knowledge of emotion and its function within a language.

\section{METHODS}

This case study is based on a corpus collected by Professor Norbert Dittmar of the Free University in Berlin. The present author has analysed this corpus in previous research (Braber, 2001). The corpus contains a series of interviews carried out in the early 1990s by students of the Free University of Berlin, who were looking at the different experiences of East and West Berliners regarding the fall of the Berlin Wall and German unification. Dittmar has written about the different forms of narration and other grammatical aspects found in the corpus in a book entitled Die Sprachmauer ('The Language Wall', with Ursula Bredel, published in 1999). There, he devotes part of his attention to the use of the modal particles eben and halt as markers of regional speech. Although this aspect will be briefly touched upon in the present article, the main interest here will be in the usage of these modal particles and tags in conjunction with emotion displayed by the speakers.

Originally, the interviews were carried out by students in 1993/4 with a view to publishing a selection of recollections of the fall of the Wall and the period thereafter from the viewpoint of East Berliners. However, the interviews turned out to be so informative that it was decided to carry out the same interviews with West Berliners. The 29 interviews with people from East Berlin and the 24 with people from West Berlin contain conversations about November $9^{\text {th }} 1989$, the night the Berlin Wall fell; the interviewees were also asked how their lives had changed since that time and how they felt about the situation in Germany after unification. Some of the interviewees are referred to by their first names, while others have been given pseudonyms describing their occupation. For example speaker 8 of the West Berlin speakers is called 'Aldi', referring to the supermarket chain in which he works; similarly, Kita, speaker 13 of the East Berlin corpus, works as a kindergarten teacher ('Kita' is an abbreviation for Kindertagesstätte, 'child day care centre'). A few of the interviews are with more than one interviewee. 
Other corpora collected around this time would likewise have been available for examination. However, for various reasons, these corpora were not as well suited for the present research as was the Dittmar corpus. Kühn \& Almstädt (1997) compare work reports written between 1990 and 1995 by East Germans in East Germany with work assessments written prior to 1989 in the GDR. Reiher (1997) examines advertisements for housing vacancies and notices written before and after unification. Neither of these corpora are suitable, as they deal exclusively with written texts, leaving very little scope for the use of modal particles. Among the other spoken language corpora available, Antos and Schubert's (1997) focuses on telephone advice sessions and consultations involving East and West Germans. This corpus was unsuitable, however, on account of the two sides being unequal, with the West Germans in the position of advice-givers and the East Germans in that of the advicetakers; consequently, the corpus did not allow for a direct comparison between the two groups. Finally, Auer (1997) analysed role-play job interviews in 1993 in Rostock, as compared with actual interviews held in 1995, and contrasted these findings with data available for West Germans. This corpus is less useful, as it concerns the more formal language usage expected in a job interview situation, and thus would tend not to involve any use of modal particles.

The Dittmar corpus was particularly appropriate for our purpose, since the $9^{\text {th }}$ November 1989 stirred especially deep emotions in the East Berlin speakers, as compared to the West Berlin speakers (see also Dittmar and Bredel 1999:31). East Berlin speakers were interviewed by East Berliners and West Berlin speakers by West Berliners to prevent blockage due to the very East-West discrepancy that was under examination. Bredel (co-author of Die Sprachmauer) remarks that that friends interviewing each other meant that there was more scope for emotions and feelings (Bredel 1999:33).

As to the interviewees, even though gender and age were represented fairly equally, there are indeed a large number of teachers among them. While the selection of interviewees thus is not representative of the total population, nevertheless it highlights another, very interesting aspect: not only are teachers, in contrast to other people, used to speaking for long stretches of time, but in general, they are aware of their language, and thus may be expected to be able to control their language use more, and more consciously, than many other speakers do. Therefore, if we still find that teachers show greater signs of emotion, and use a greater number of modal particles, when talking about emotional events, such a result is all the more telling.

In previous research (Braber, 2001), I examined five different modal particles : eben, halt, doch, denn and eigentlich. These modal particles all have very different functions in German, and each of them is used differently in different contexts. The modal particles (among which, due to constraints of space, only two will be discussed here : eben and halt) have individual characteristics; in particular, eben and halt are not mere synonyms. Eben tends to emphasize a kind of finality on the part of the speaker: it suggests that there is no real alternative to the suggestion being made; it can also indicate that the speaker agrees with what is being said. Moreover, eben can be used to conclude the argument of another speaker, or sum up a previous conversation.

Until recently, eben and halt were generally seen as synonymous, but used in different parts of Germany: eben in the North and halt in the South. It has now become clear that this is not always the case; these two modal particles are not always interchangeable (Hentschel 1982:235), and furthermore they can be combined. Even 
so, halt still suggests a feelings of finality; it is also used to give advice or make a suggestion.

It has also been hypothesised (e.g. Hentschel 1982; Dittmar 1997; Dittmar and Bredel 1999) that halt is warmer and friendlier than eben. In the present article, it will be the actual usage of modal particles that will be discussed, rather than the individual 'meanings' of such words. These two modal particles will play an important role as markers of speaker identity in the data analysed. Since halt was originally seen as coming from South Germany, its usage has been perceived as spreading upwards throughout the rest of Germany, with the exception of the GDR. Within the GDR, its usage would have sounded 'western' and most GDR citizens would have tried to avoid it (some preliminary analyses of usages of eben and halt are found in Dittmar 1997 and Dittmar 2000).

The interviews seem to take a different course depending on where the speaker comes from: the East Berliners tend to discuss how they coped with the changes emotionally and talk about the problems they came across, whereas the West Berliners talk less of the actual night of $9^{\text {th }}$ November, but talk more of the times afterwards, when they had to help and advise their new compatriots; some also talk about the ways in which they profited from the changes. The West Berliners also frequently discuss the times when relatives from the East visited them before 1989 and how they were able to help them.

My analysis is qualitative rather than quantitative: rather than aiming for a statistical analysis of modal particle usage, I consider the content of the usage to be of ultimate importance. This is especially relevant as the interviews vary in length and the numbers of East and West Berliners interviewed differ; hence measuring overall usage would not have been as effective. The fact that the interviews were recorded on tape and later transcribed made it less complicated to count modal particle usage than would have been the case if one had to rely exclusively on recordings. For each interview, the occurrence of each modal particle was counted and divided by the number of transcript pages in order to obtain an average per page; this would rule out any difference due to different interview length. Putting these counts onto graphs (see below, section 3), with the individual speaker's assigned number on the horizontal axis and the respective counts on the vertical axis, makes the differences clearly visible. Every graph also shows each modal particle's average use, represented by a dotted line; the lines showing statistical significance are always present at the top of the graph and in some cases additionally at the bottom. All the speakers whose usage crosses either the upper or lower line can be said to be statistically significant in their use of the modal particle in question. The average line allows us to compare the different particles as to their different usage in East and West, as well as doing within-group comparisons. In this way, the graphs' main function is to visualise the significant differences in usage.

What comes to light first on examining the graphs is the quantitative difference between people from East and West Berlin in the use of modal particles, as demonstrated in the levels of usage. The question is whether this quantitative difference is due to a link between modal particles and emotion. Modal particles occur more frequently in informal language situations, and also in situations where difficult topics are discussed. They can also be seen as showing greater usage of dialect, something for which the East Germans, and specifically the East Berliners, were known. Especially in East Berlin, Berlinisch was an accepted form of language in all 
situations; this was very different from the situation in West Berlin, where such usage was frowned upon. However, in the interviews, the increased usage of modal particles and tags by East Berliners is clearly not just due to dialect usage: it reflects the emotional situation of the speakers. For the East Berliners, the fall of the Wall and German unification were very emotional and important topics since for them, the changes of 1989 led to a completely different way of living. The West Berliners, in contrast, could view the changes from a more objective, distanced angle.

\section{RESULTS}

\subsection{Eben}

[Figure 1 around here]

Fig. 1 shows the usage of eben in East Berlin. Four of the speakers use eben in a statistically significant way (speakers 3, 5, 22 and 26), while one speaker (25) does not use it at all. Speaker 3, Gabi, the highest eben user in the corpus, used to be a dancer in the former GDR; after unification, when her dance group was disbanded, she has been unemployed. Gabi mentions in the interview that she feels much more at home in East Berlin and mentions that West Germany is not as good as it had been made out to be. Her usage of eben is particularly frequent when she gets excited about her subject, as becomes very obvious when she is discussing the different employment opportunities for East and West Germans. Gabi does not use halt at all in her interview. Speaker 5 is Micha, a 33 year old skilled worker and lorry driver. He uses eben very significantly throughout his interview. It is noticeable that he, too, uses it most when he discusses an emotionally laden subject. Although he did not always agree with the way the GDR was run, he does have strong opinions about what has been happening in Germany since 1989. Similarly to Gabi, he does not use halt at all. Speaker 22 is Lore, a 50 year old teacher from East Berlin. Throughout, she is very emotional when telling the interviewer about the things which affected her at the time of the Wende as well as in more recent years. At certain points in the interview, she is close to tears; she mentions that she cried a lot during November 1989. Although Lore uses eben throughout the interview, the occurrences cluster together at certain points; she only uses halt once in the entire interview. Speaker 26 is Willy, a newly trained teacher in his mid- to late twenties. Willy is an interesting speaker as he can see both the positive and negative sides of what happened to Germany in 1989. He tries to be calm and consider both sides of the argument. He is the second highest eben user in the corpus and similarly to Lore, he uses it throughout the interview, although it clusters together at particular points. Again, he does not use halt at all.

The only speaker of the East Berlin corpus who never uses eben is speaker 25, Rainer. All that is known about him is that he is what used to be called, in GDR terminology, a Republikflüchtiger (literally, 'an escapee from the GDR'). ${ }^{2}$ In September 1989 he obtained a visa to travel to Bulgaria, with travel through Hungary. He first flew to Bulgaria, then went by train to Hungary; once there, he approached the Red Cross, who arranged for bus travel to West Germany, from where he moved to West Berlin. In his interview, he sounds like he is reading from a written text. He rarely uses modal particles at all and he does not use tags either, which could indicate that he is controlling his speech. 
[Figure 2 around here]

Fig. 2 illustrates the usage of eben by speakers from West Berlin. Among the East Berlin speakers, its average use is lower than it is among speakers from West Berlin (in fact, East Berliners use eben twice as often as do West Berliners; Dittmar 2000:17); also, there are more West Berlin speakers who do not use it at all. Only four of the West Berlin speakers use eben above the level of statistical significance (speakers 3, 15, 16 and 18); five do not use it at all (speakers 7, 10, 13, 23 and 24).

Looking first at those speakers who use eben above the level of statistical significance, we find speaker 3, Alina, a 51 year old carer for the elderly. Hers is an interesting mix of modal particles, most of which she uses very frequently. Alina is the second highest user of eben in the West Berlin corpus, using it evenly throughout the interview, but particularly in the last part, where she talks about how the East Germans must have felt after the Wall came down and about the identity problems they may have suffered from since 1989. As to halt, Alina uses it much less frequently, even though well above the average for a West Berlin speaker. As the usage of halt in West Berlin is still a relatively new occurrence, the fact that for Alina, eben still is the preferred choice could have something to do with her age. Speakers 15 and 16 are Christine and Jens, a married couple, 49 and 52 years old. Christine is a teacher at a primary school, Jens at a secondary school. Both Christine and Jens use eben frequently; Jens is the highest eben user in the West Berlin corpus. Even so, there is a significant rise in their use of eben, namely when the two discuss things which lie close to their hearts: sometimes these are situations that their East German friends have found themselves in, or how these friends' lives were different before 1989. Interestingly, these two eben users are close in age to speaker 3, Alina, who was also a significant user of eben. The last speaker who uses eben above average is speaker 18, Rolf, whose age and occupation are not known. He is the typical case of a speaker who is not aware of his language use; except for the first few minutes, when he seems rather nervous, he uses eben throughout the entire interview. When the interviewer asks Rolf about the different usages of eben and halt in Berlin and how he uses the particles himself, Rolf comments that the only one he ever uses is halt; he also mentions that he is in possession of a good feeling for how to use language with regard to these matters (his Sprachgefühl, as he calls it). Even so, he does not use halt at all during the interview, in contrast to eben, which he uses 45 times.

The first West Berlin interviewee who does not use eben at all is speaker 7, Markus, a 27 year old student. His attitude towards East Germany and unification is very positive. He uses very few modal particles and tags, but this could be due to the fact that he is trying to speak formally. The interviewer, who is a good friend of his, comments on the cover sheet that Markus seems unsure and is trying very hard to speak Hochdeutsch (Standard German). The fact that eben is lacking in Markus' speech could be related to his age: with the general use of halt penetrating the West Berlin speech community from the South, Markus's higher use of halt (although still being below average) could be explained in this way. Speaker 10 is Ernst, a 35 year old kindergarten teacher. In a separate comment, the interviewer remarks that Ernst seems stressed; actually, Ernst is one of the few interviewees who do not know their interviewer, and this could influence his language use, as well as affect his general feeling of confidence and comfort. Ernst likewise does not use eben at all; he is also a 
very high halt user (I will discuss this below). Ernst seems never to have had much contact with East Berlin or East Germany, not even since the Wall came down; he remarks that he was not in any way affected by the changes which occurred in 1989 and does not have any particular positive or negative feelings about them. Speaker 13, Pia, is a 46 year old psychologist who is similarly involved in education. Pia is different, as she is one of the very few people who uses neither eben nor halt; this could be due to the fact that her interview is relatively short, or perhaps be attributed to her educational training. (Pia's case will be discussed in more detail below, when I examine tag usage in West Berlin). The last two speakers who do not use eben are speakers 23 and 24, Berta and Caroline, both students. Their lacking eben usage could be have to do with their age. Interestingly, both study at Humboldt University (which is located in East Berlin and has a majority of East German students). Both do use halt and Berta is one of the prominent users in the West Berlin corpus.

Although eben is still more common than halt among most Berlin speakers (cf. also Dittmar and Bredel 1999:159), there are also clear differences in the ways the speakers are using this modal particle. East Berliners use eben twice as much as do West Berliners (Dittmar and Bredel 1999:160). ${ }^{34}$

\subsection{Halt}

[Figure 3 around here]

The usage of halt in East Berlin is much lower than that of eben and there are many speakers who never use it at all; as Fig. 3 shows, 15 of the 29 interviewed speakers do not use halt. Apparently, halt has not yet spread to East Berlin the way it has to other parts of Northern Germany. Given that in our corpus, many speakers never or rarely use halt, the analysis will only concern the four speakers who do use it significantly (speakers 1, 7, 15 and 16). Amomg these speakers, certain social patterns, (such as their integration into a new society; Dittmar 2000:19, 22) may be observed.

Speaker 1, Gina, who as noted above, uses eben above the level of statistical significance, also shows a higher than average usage of halt; in addition, Gina frequently uses the combination eben halt. ${ }^{5}$ Gina now works in West Berlin, and her use of halt could have been influenced by the people surrounding her in her new work environment. Speaker 7 is Bert, a male nurse who has lived in Munich since 1991 when he found work there, even though this has meant leaving his wife and family behind in Berlin, since they did not want to move. He is the highest halt user in the East Berlin group (his use of eben is below average). Bert's usage of halt seems to be influenced by his stay in Bavaria, where it is the modal particle in common use. Interestingly. despite his continued and very frequent contact with East Berlin and his family, his language use seems different from that of most East Berliners. Speaker 15 is Gitta, a 28 year old secretary who fled the GDR via the West German embassy in Prague in 1989. It seems that, as in the case of Bert, her social circumstances influence her language use. Thus, Gitta uses eben well below the East Berlin speaker average; her use of halt is perhaps her way to distance herself from the society she left behind, the GDR. The only time Gitta combines eben and halt is at a particularly emotional moment in the interview, when she recounted how she and her family were driving to Prague to try and reach the West German embassy. They were warned that the place was heavily guarded, so they entered the West German embassy on foot with the help 
of some journalists, leaving all their possessions behind in their car. The final speaker who uses halt significantly is speaker 16, Dolly, a 27 year old woman who, while in the GDR, was in the catering business, but now is training to be a medical technician. Dolly very rarely uses eben at all (in fact, only twice during the entire interview); in contrast, she uses halt very frequently. Dolly mentions that in her previous job, she had a lot of contact with West Germans and West Berliners, and this could have influenced her language usage. One of the occasions of her frequent use of halt is when she describes how hard life is for East German people in the new Germany; as to herself, she does not have much money and cannot buy many of the new products which are now available.

Overall, for many of the East Berlin speakers, halt still seems to be a marked form; it is used less frequently by most of them than is eben. Those who do use halt are often younger and have more contact with West Berliners.

[Figure 4 around here]

For the speakers from West Berlin, the gap between eben and halt is not as large as it is in the case of the East Berliners. For both modal particles, the average usage is the same, and there are only slightly more West Berlin speakers who never use halt (out of a total of 24 speakers, five never use eben and eight never use halt). There are only four West Berlin speakers whose use of halt is statistically significant (speakers 2, 9, 10 and 23). As there are eight speakers who never use halt and all but four who use it very infrequently, it will not be possible to discuss these speakers here (for details, see Fig. 4).

Speaker 2, Norman, is one of those who use halt above the significance level. Norman is in his twenties, is involved in sales, and has been doing well since unification; he mentions that he does not feel at all affected by the Wende. In contrast with his halt usage, he uses eben very sparingly. Norman has many strong opinions which he expresses throughout the interviews. Although he has, or used to have, relatives in the GDR, he does not feel very close to them and thinks they have a completely different way of thinking. On the whole he does not sympathise with East Germans; he thinks they're always complaining ('moaning') about something. ${ }^{6}$ Interestingly, the occasions on which Norman's use of halt frequently are those when he mentions that he used to be happier with the situation of West Berlin before the Wende: it used to be a nice 'island' and because of this, it was a special place, but now it is the same as any other place. Speaker 9 is an unnamed woman of 19 who is training to work in a pharmacy. She is described as speaking very quietly and does not seem very sure of herself. While she does not use eben at all, she uses other modal particles to a large extent: in fact, she is the highest user of halt among the West Berlin speakers and the second highest user in the entire corpus (perhaps her young age and the growing popularity of halt are responsible for her frequent use of this particle). This speaker uses halt consistently throughout her interview, although she does not use it in combination with any other modal particles or tags. Contrary to what we see in the East Berlin interviewees, this speaker seems to be uncertain of exactly what happened around the time of $9^{\text {th }}$ November, in particular at what time she went to join the crowd at the Wall. Speaker 10 is Ernst, the 35 year old kindergarten teacher who was briefly discussed earlier in connection with his non-use of eben in his interview. Ernst does, however, use halt frequently; one of the points where he uses it is when he mentions 
his nervousness the first time he crossed into East Berlin, although this was already after November 1989. He also mentions that he was not sure whether he should be happy or not when he heard that the Wall had fallen. Finally, speaker 23 is Berta, a student who is now enrolled at the Humboldt University.She uses halt particularly frequently when talking about the initial fears among East German students when West German students joined their courses at the University. Also, when she is talking about how well she was getting on with the people in her class, Berta's use of halt goes up dramatically. Apparently, she uses this particle to highlight things that are important to her and that she feels strongly about.

\subsection{Tags}

[Figure 5 around here)

It is in their use of 'tags' (expressions such as isn't it, doesn't he in English, nicht wahr, ne and wa in German, the last form being particularly common in Berlin) that the two groups in the corpus show their differences most clearly. Although tags overall do not fulfil the same functions as do modal particles, there are certain interesting similarities (among other things, tags seem to reflect the level of emotion in the interviews, which is why they are discussed in this connection). Fig. 5 shows the very high tag usage that is characteristic for East Berlin speakers, the average being approximately 4 per page of transcript, which is higher than that of any of the other modal particles examined here. Only three speakers (9, 25 and 28) never use tags at all; three other speakers (1, 5 and 10$)$ use it above the level of statistical significance (see Fig. 5). Among the speakers who use tags very frequently is speaker 1 , Gina, the third highest tag user in the East Berlin corpus; she frequently uses tags in isolation, but also quite often in conjunction with the other modal particles. Gina uses tags throughout the interview except when she talks about her friends and describes what has happened to them since unification. Speaker 5 is Micha, the lorry driver with the strong opinions on the situation in Germany since 1989. He uses tags such as ja and ne consistently throughout his interview; this is particularly noticeable when he is talking about art and culture. Except during the first few minutes, where he presumably is trying to appear as a 'good' speaker and uses almost no modal particles, tags, or vocabulary that is likely to be considered dialectal, Micha freely uses tags in his conversation. While in his use of dialect, Micha is similar to Dirk (speaker 3 in the East Berlin corpus), the two are very different when it comes to modal particles and tags: Micha is a very high modal particle and tag user, whereas such expressions occur only rarely in Dirk’s speech, which is surprising as he does use dialect throughout his interview. Speaker 10 is Assi, a 36 year old primary school teacher. In this interview, the speakers become more and more excited as the interview progresses, and start speaking faster and interrupting more. The tag ja occurs very frequently in their speech and it is almost as if each were trying to obtain the other's approval. Incidentally, this tendency is visible many of the East Berlin interviews; some of the East Berlin speakers add remarks to the effect that many East Germans still feel rather unsure of themselves, especially when they speak with West Germans, or West Germans are around; the West German speakers seem much more self-assured. As is well known, tags can be used to seek agreement from one's conversational partner (compare that Anglo-American research has long considered tags as signalling a lack of power; cf. Winefield et al. 1989). Such 
tendencies may be an issue in many of these interviews.

Three of the East Berlin speakers (9, 25 and 28) do not use tags at all, which makes them stand out in the overall pattern of the East Berlin interviews. Speaker 9 is Angi, a teacher; she hardly uses any modal particles or tags. Her interview is very short, and therefore her data are more difficult to analyse; yet they make sense in their own right. Angi starts out by saying that the main thing she remembers about $9^{\text {th }}$ November 1989 is that she was sick in bed all day. Although she does mention that she remembers seeing people on the television crying and being emotional, it is clear that she kept a certain distance from the events. This could also be one of the reasons that her interview is so short, as her remembrances of those times are not as strong as those of most other (East and West Berlin) speakers. As to German unification, she is not sure if the process perhaps did not move too fast. Again, rather than representing a personal experience, this is a more distanced opinion; Angi is trying to voice an objective view of the events, and this is also reflected in her sparing use of emotionladen elements, such as modal particles and tags. Speaker 25, Rainer, is one of the three speakers who escaped from the GDR in September 1989. As mentioned previously, his interview sounds almost as if it were prepared in advance; this type of language use does not allow for modal particles and tags. Speaker 28, is Konrad, another 'GDR escapee' (Republikflüchtiger), who fled East Germany together with his wife, Gitta (speaker 15). Konrad does not use modal particles or tags to any great extent, apart from the expression eigentlich (literally 'actually, really'), which he uses to explain situations.

When we look at the pattern of tag usage in West Berlin, we notice right away that it is very different from that of East Berlin. (See Fig. 6)

[Figure 6 around here]

The average usage is down to around one per transcript page (compared to four in East Berlin); none of the West Berlin speakers use tags to the extent that the East Berliners do. There are only two speakers who use tags above the level of statistical significance; these are speakers 8 and 13. Five speakers (3, 5, 7, 10 and 12) never use tags at all; many of the other speakers use them rarely. Speaker 8, the man known as 'Aldi' (after the shop where he works is a 57 year old male who has had many different jobs. 'Aldi' is a real story-teller, and enjoys talking, which makes it all the more surprising that he uses hardly any modal particles, especially as other 'story-tellers' frequently use such elements (including the expression eigentlich, see above) in their narrations. On the other hand, 'Aldi' is the second highest tag user in the West Berlin corpus, with a frequency that is well above the level of significance. At the beginning of his interview, there are not quite as many occurrences of tags, perhaps due to his being slightly nervous or apprehensive at being recorded. However, after this, 'Aldi' uses tags very often to explain what he is saying; he seems to be using tags mainly to gain affirmation from the interviewer, something which occurs frequently in the East Berlin interviews (as we have seen above). The highest tag user in the West Berlin corpus is speaker 13, Pia, the psychologist. She uses tags as signals of emotion, notably to express her views and opinions on $9^{\text {th }}$ November 1989 and the subsequent German unification. Pia is unusual in that she is among the few West Berliners who felt 'trapped' in West Berlin: upon returning to West Berlin, every time she would feel like she was back in the 'witches' cauldron' (Hexenkessel). For Pia, it is very important 
that her children do not distinguish between East and West Berlin any longer. She is also unusual in that she comments that there are no linguistic differences between East and West Berlin and that they all speak the same language (or dialect).

There are five speakers who never use tags: speakers 3, 5, 7, 10 and 12. Speaker 3 is Alina, the same speaker whose usage of eben and halt has been discussed earlier. Alina gives a rather emotional account of $9^{\text {th }}$ November and uses many modal particles throughout her interview. She seems to use these modal particles to express her feelings and opinions about many subjects, and also in order to enrich her descriptions; however, for some reason or other she never uses tags to express, or expand on, her feelings. The reason could be that for Alina, tags do not fit in with the more formal type of language that one would expect in an interview such as this ; but then it is not clear why she would persist in using all these many modal particles. Perhaps, because of her frequent particle use , Alina feels no need for tags; in that case, her case would be different from the many other speakers who do use both tags and modal particles. Speaker 5 is Manuela, a 29 year old pediatric nurse who studied to be a primary school educator. Manuela uses few modal particles (except for eben, which she uses more than the average) and no tags; this may stem from a lack of involvement: her participation in the discussion at no point seems overly enthusiastic. Speaker 7 is Markus, the 27 year old student. He does not use tags at all, which could be due to the fact that he is attempting to speak formally, as noted earlier. The fact that speaker 10, Ernst, the 35 year old kindergarten teacher, does not use tags, is to do with his efforts to avoid a more colloquial style when he is speaking with someone he does not know (Ernst is one of the few speakers who do not know their interviewer); this may have influenced his language style to a certain extent. Finally, speaker 12, Concha, a 48 year old speech therapist, uses very few modal particles and no tags, thereby strengthening our assumption that low emotional involvement somehow reflects itself in a lower usage of these expressions; in fact, Concha maintains that the Wende did not affect her life in any way. Another factor playing a role here could be that her training as a speech therapist and her professional control of language have permanently affected her way of speaking. Even though the protocol mentions that Concha seems relaxed and knows the interviewer, her language use remains formal throughout the interview.

\section{CONCLUSION}

Our analysis of the interviews has shown that, even after unification, the usage of eben and halt remains different in East and West Berlin. Less than half of the East Berliners use halt, as against more than two-thirds of the West Berliners. As to the usage of eben, it generally is still stronger in East Berlin than is the use of halt, perhaps as a result of the latter having been avoided during the GDR years. Halt is seen as the typically South German version of eben; and, even though it is spreading to the North of Germany, where many of the younger speakers seem to be adopting it, it evidently had not yet fully spread across East Germany and East Berlin in 1994.

More interesting, perhaps, is the fact that in emotional situations, speakers use both eben and halt. Looking at the East and West Berlin speakers individually, one notices that interviewees with a high incidence of eben and halt also show a higher emotional involvement; and conversely, speakers who do not use eben and halt are often perceived as distancing themselves from the November 1989 events. 
These usages of eben and halt may furthermore be contrasted with the use of eigentlich (which was mentioned in passing earlier; for details see Braber 2001). Eigentlich behaves like a modal particle, more specifically a downtoner it is used in narrative stretches, where it allows speakers to distance themselves from the events they are narrating.

The biggest difference between the two groups of speakers is in their use of tags, these highly under-researched facets of language. Although tags were not originally included in the analysis, as they do not come under the modal particle heading, their usage manifests obvious differences between speakers, depending on their degree of involvement in what they are saying. Tags are frequently used by both East and West Berlin speakers to obtain feedback from the interviewer. A particularly common type of tag, used in Berlin, is wa, although others, such as nicht and ne, are also frequent.

The purpose of this article has not been to show that East and West Berlin speakers use modal particles differently in normal language use. Rather than merely etablishing a distinction between speakers from East and West Berlin, the main issue here is whether one can relate, more or less directly, the speakers' increased use of modal particles and tags to their emotional states. Such a correlation is admittedly very difficult to demonstrate uncontroversially, and for that reason, many of my conclusions must remain speculative, at least to a certain extent. Still, an in-depth scrutiny of the interviews, both by listening to the tapes and simultaneously examining the transcripts, makes the link stand out clearly. Obviously, many of the topics discussed in the interviews are close to the speakers' hearts; especially, many of the East Berliners feel very affected by the changes which have occurred in their lives since 1989In contrast, as to the West Berlin speakers, many of these changes seem not to have affected the interviewees too personally. It is facts and observations like these that are reflected in the speakers' use of language.

Modal particles and tags are chosen for a variety of reasons. It is well documented that modal particles appear more frequently in informal language situations and in situations where difficult topics are discussed. Thus, the interviewees' increased use of modal particles and tags seems to be connected to the expression of feelings about such topics, for example the fall of the Wall and the aftermath of German unification. In particular, as regards the East Berlin interviews, the increased use of modal particles and tags may manifest a greater emotional involvement, even when the speakers are not aware of it themselves. Finally, the usage of particles and tages is also related to the speakers' choice or preference of dialect. Here, one should remember that, while in the GDR, the use of dialect was acceptable in all discourse situations, this was certainly not the case in West Berlin, where Berlinisch was looked down upon. Clear, this influences the likelihood of a particular particle or tag occurring in different speakers' use of language.

Whereas some linguists have wondered whether the German modal particles were superfluous, as they can be left out of sentences without significantly altering the latter's truth values, our analysis strongly suggests that there is a relation between the arousal and expression of feelings on the one hand, and the use of modal particles and tags in German on the other. The modal particles and tags reviewed here thus serve very important functions in German (as in many other languages). Although more research is needed, both on German and on other languages (whether or not they use modal particles), our preliminary results suggest the existence of a clear connection 
between language and emotion. 


\section{REFERENCES}

Abraham, Werner, 1995. Wieso stehen nicht alle Modalpartikeln in allen Satzformen? Deutsche Sprache 23, 124-146.

Adler, H.G., 1964. Füllwörter. Muttersprache 74, 52-55.

Antos, Gerd and T. Schubert, 1997. Unterschiede in kommunikativen Mustern zwischen Ost und West. Zeitschrift für Germanistische Linguistik 25, 308-330.

Auer, Peter, K. Birkner \& Friderike Kern, 1997. Wörter - Formeln - Argumente. Was in Bewerbungsgesprächen ,Spaß’ macht. In: Barz, I. \& Fix, U. (Eds.), Deutschdeutsche Kommunikationserfahrungen im arbeitsweltlichen Alltag, Heidelberg, Universitätsverlag C. Winter, 213-231.

Baerentzen, Per, 1989. Syntaktische Subklassifizierung der Fügewörter im Deutschen. In: Weydt, H. (Ed.), Sprechen mit Partikeln, Berlin, Walter de Gruyter, 19-29.

Battachi, Marco W, T. Suslow and M. Renna, 1996. Emotion und Sprache (Zur Definition der Emotion und ihren Beziehungen zu kognitiven Prozessen, dem Gedächtnis und der Sprache). Frankfurt am Main, Peter Lang.

Bloom, Lois and Richard Beckwith, 1989. Talking with Feeling: Integrating Affective and Linguistic Expression in Early Language Development. Cognition and Emotion 3, 313-342.

Braber, Natalie, 2001. The German Language and Reunification 1990: The Effect of Emotion on the Use of Modal Particles in East and West Berlin. Unpublished PhD manuscript, University of St. Andrews.

Bredel, Ursula, 1999. Erzählungen im Umbruch - Studie zur narrativen Verarbeitungen der 'Wende'. Tübingen, Stauffenburg Verlag.

Bublitz, Wolfram, 1978. Ausdrucksweisen der Sprechereinstellung im Deutschen und Englischen. (Untersuchungen zur Syntax, Semantik und Pragmatik der deutschen Modalpartikeln und Vergewisserungsfragen und ihrer englischen Entsprechungen). Tübingen, Max Niemeyer Verlag. Burkhardt, Armin, 1982a. Abtönungspartikeln als Mittel des Vollzugs Präsuppositionaler Akte. Zeitschrift für Germanistische Linguistik 10, 85-112. Burkhardt, Armin, 1982b. Gesprächwörter. In: Mentrup, W. (Ed.), Konzepte zur Lexikographie, Tübingen, Max Niemeyer Verlag, 138-171.

Caffi, Claudia and R.W. Janney, 1994. Towards a Pragmatics of Emotive Communication. Journal of Pragmatics 22 , 325-373. (Special Issue, Involvement in Language)

Dittmar, Norbert, 1997. Sprachliche und kommunikative Perspektiven auf ein gesamtdeutsches Ereignis in Erzählungen von Ost- und Westberlinern. In: Barz, I. \& Fix, U. (Eds.), Deutsch-deutsche Kommunikationserfahrungen in arbeitsweltlichen Alltag, Heidelberg, Universitätsverlag C Winter, 1-32.

Dittmar, Norbert, 2000. Sozialer Umbruch und Sprachwandel am Beispiel der Modalpartikeln halt und eben in der Berliner Kommunikationsgemeinschaft nach der ,Wende’. In: Auer, P. \& Hausendorf, H. (Eds.), Kommunikation in gesellschaftlichen Umbruchsituationen, Tübingen, Niemeyer, 199-234.

Dittmar, Norbert and Ursula Bredel, 1999. Die Sprachmauer. Berlin, Weidler Buchverlag.

Ekman, Paul and R.J. Davidson, 1994. The Nature of Emotion. Oxford, Oxford 
University Press.

Frijda, Nico H., 1969. Recognition of Emotion. In: Advances in Experimental Social Psychology, volume 4. London, Academic Press, 167-223.

Hartog, Jennifer and M. Ruttenauer, 1982. Über die Partikel 'eben'. Deutsche Sprache 10, 69-82.

Helbig, Gerhard, 1988. Lexikon deutscher Partikeln. Leipzig, VEB Verlag

Enzyklopädie.

Hentschel, Elke, 1982. Halt und eben. In: Detering, K., Schmidt-Radefeldt, J. \&

Sucharowski, W. (Eds.), Linguistische Arbeiten - Sprache erkennen und verstehen,

Tübingen, Max Niemeyer Verlag, 231-241.

Heringer, Hans-Jürgen, 1988. Ja, ja, die Partikeln! Können wir Partikelbedeutungen prototypisch erfassen? Zeitschrift für Phonetik, Sprachwissenschaft und

Kommunikation 41, 730-754.

Holmes, Janet, 1982. The Function of the Tag Question. English Language Research Journal 3, 40-65.

James, William, 1967. What is an Emotion? In: Dunlap, K. (Ed.), The Emotions, New York, Hafner Publishing Company, 93-135.

Karagjosova, Elena, 2003. Modal Particles and the Common Ground. Meaning and Functions of German ja, doch, eben/halt and auch. In: Kühnlein, P. (Ed.), Perspectives on Dialogue in the New Millennium, Amsterdam, Benjamins, 335-349.

König, Ekkehard, 1991. The Meaning of Focus Particles - A Comparative Perspective. London, Routledge.

König, Ekkehard, 1997. Zur Bedeutung von Modalpartikeln im Deutschen: Ein Neuansatz im Rahmen der Relevanztheorie. Germanistische Linguistik 136, 7-75.

Kühn, Ingrid and K. Almstädt, 1997. Deutsch-deutsche Verständigungsprobleme. Der Deutschunterricht 49, 86-94.

Molnár, Anna, 1996. Modalpartikeln als selbständige Wortart. Sprachtheorie und germanistische Linguistik 2, 125-133.

Molnár, Anna, 1998. Über die Grammatikalisierung von Modalpartikeln am Beispiel von eben und wohl. Sprachtheorie und germanistische Linguistik 8, 51-70.

Molnár, Anna, 2004. Review of Tanja Autenrieth. Sprachtheorie und germanistische Linguistik 14, 69-77.

Reiher, Ruth, 1997. Dreiraum- versus Dreizimmerwohnung. Der Deutschunterricht 49, 42-49.

Stevenson, Patrick, 2002. Language and German Disunity. A Sociolinguistic History of East and West in Germany, 1945-2000. Oxford, Oxford University Press.

Waltereit, Richard, 2001. Modal particles and their Functional Equivalents: A SpeechAct-Theoretic Approach. Journal of Pragmatics 33, 1391-1417.

Weydt, Harald, 1969. Abtönungspartikeln - Die deutschen Modalwörter und ihre französischen Entsprechungen. Bad Homburg, Verlag Gehlen.

Winefield, Helen R; M A Chandler; D L Bassett, 1989. Tag questions and Powerfulness: Quantitative and Qualitative Analyses of a Course of Psychotherapy. Language in Society 18, 77-86. 


\section{FOOTNOTES}

${ }^{1}$ This emotionally loaded term (more or less intended to mean: 'one who has betrayed our Republic') was used by the GDR authorities denounce those who had escaped from East Germany. In West Germany these people were referred to by the more neutral term DDR-Flüchtlinge (literally, 'refugees from the GDR').

${ }^{2}$ Norman refers to this as ewige 'rumjammerei. This is a term which was used by many West Germans to express their low opinion of the East Germans, and led to the nickname Jammerossi, literally: ‘moaning East German'.

${ }^{3}$ These authors also comment on the fact that East Berliners use the variant ebent whereas West Berliners do not use this form at all; according to Dittmar and Bredel (ibid.), the final consonant is stigmatized in West Berlin and was only used in East Berlin and the surrounding region of the former GDR (now the Land) Brandenburg.

${ }^{4}$ See Dittmar and Bredel (1999, 160-161) for a discussion of the different types of speakers, those who use both eben and halt and those who use only the one or the other. 


\section{FIGURES}

Figure 1: Eben in East Berlin

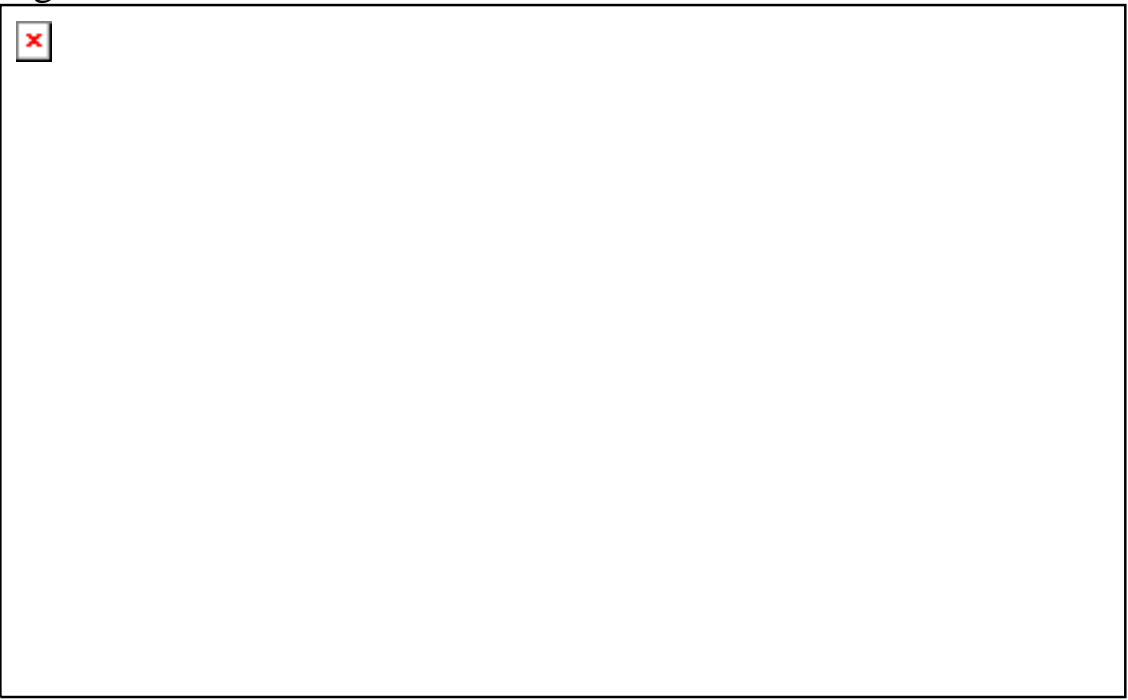

Figure 2: Eben in West Berlin

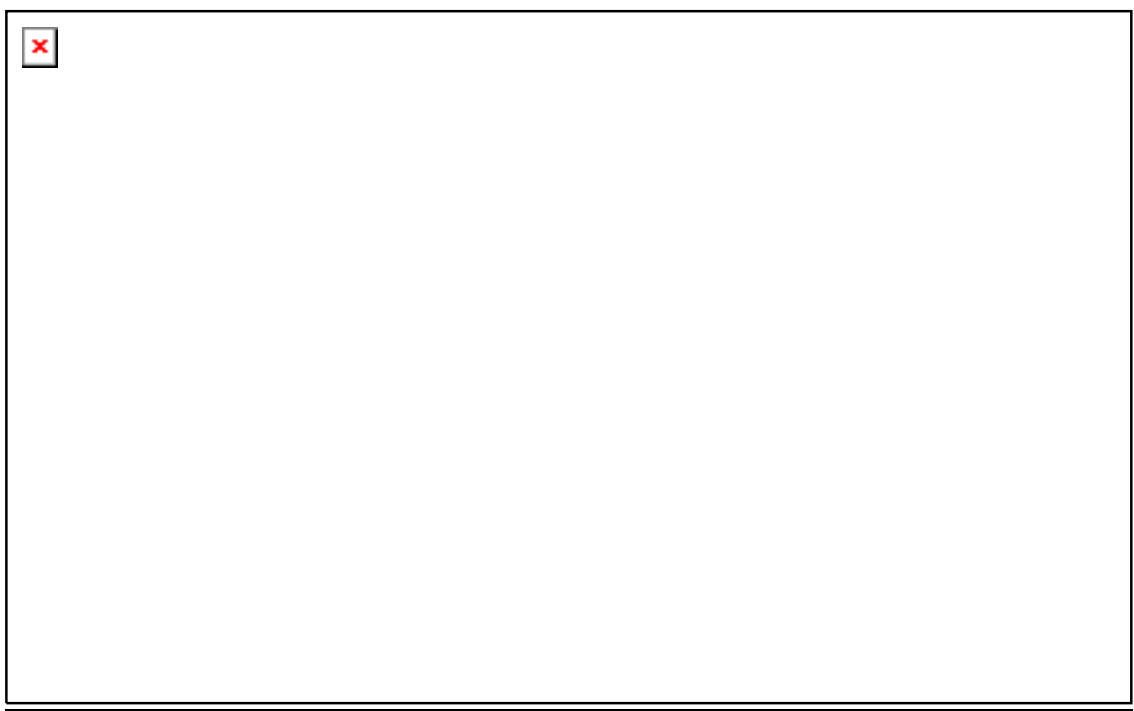

Figure 3: Halt in East Berlin 


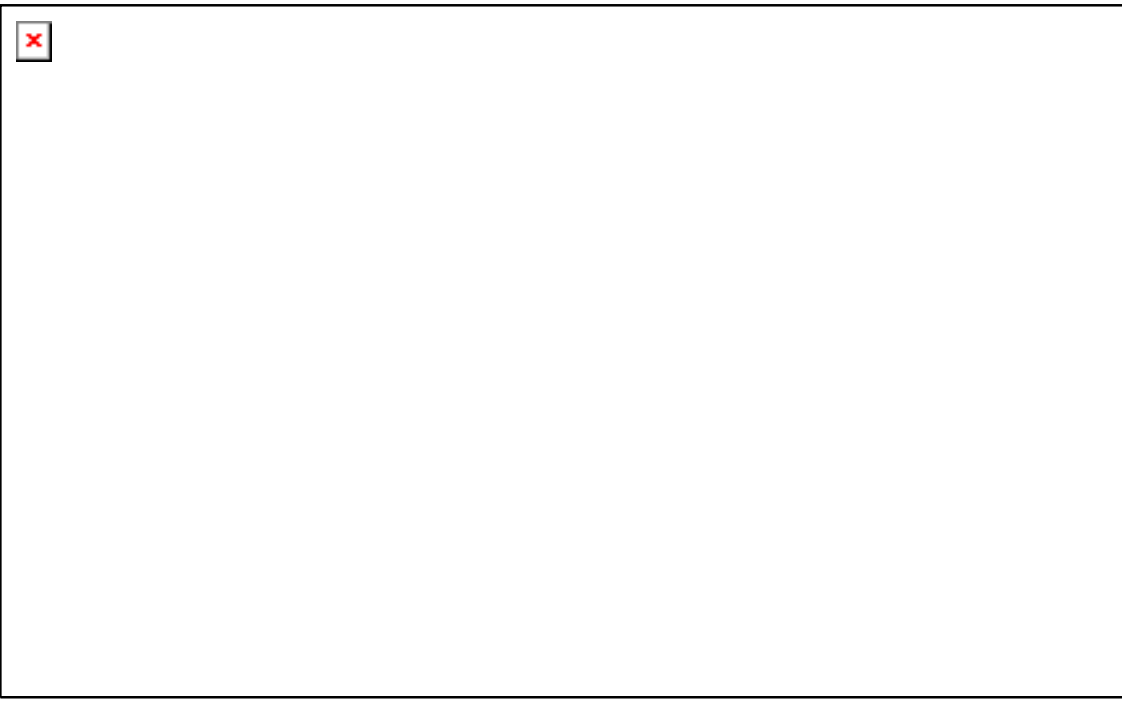

Figure 4: Halt in West Berlin

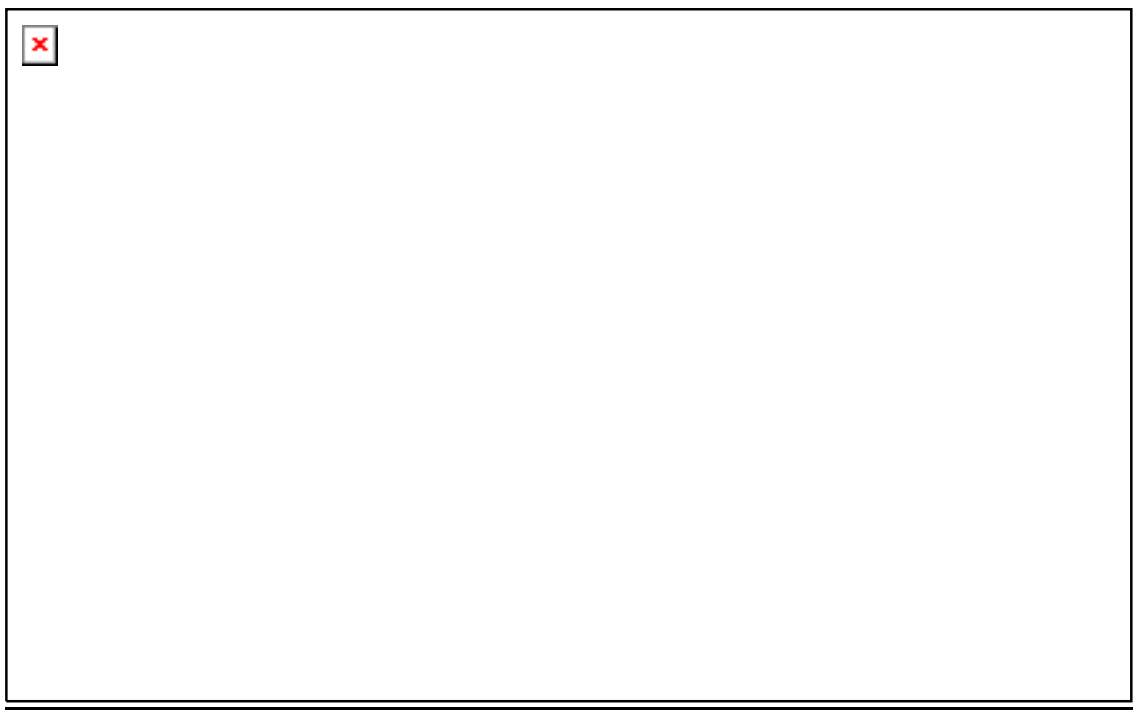

Figure 5: Tags in East Berlin 


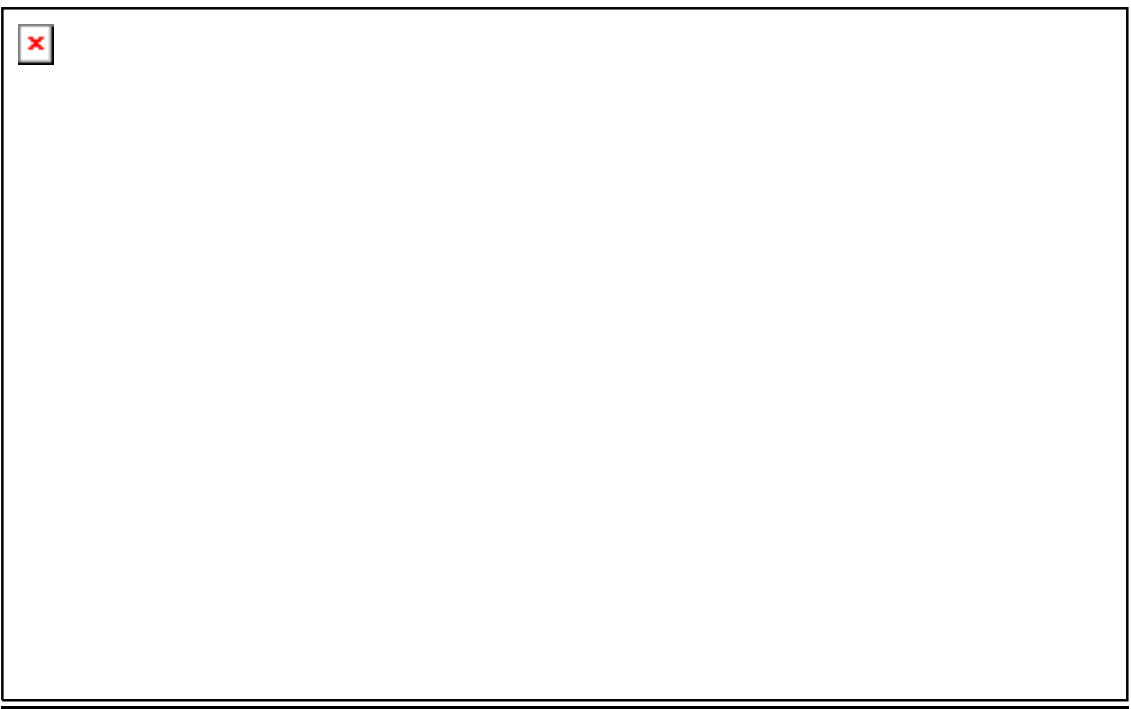

Figure 6: Tags in West Berlin

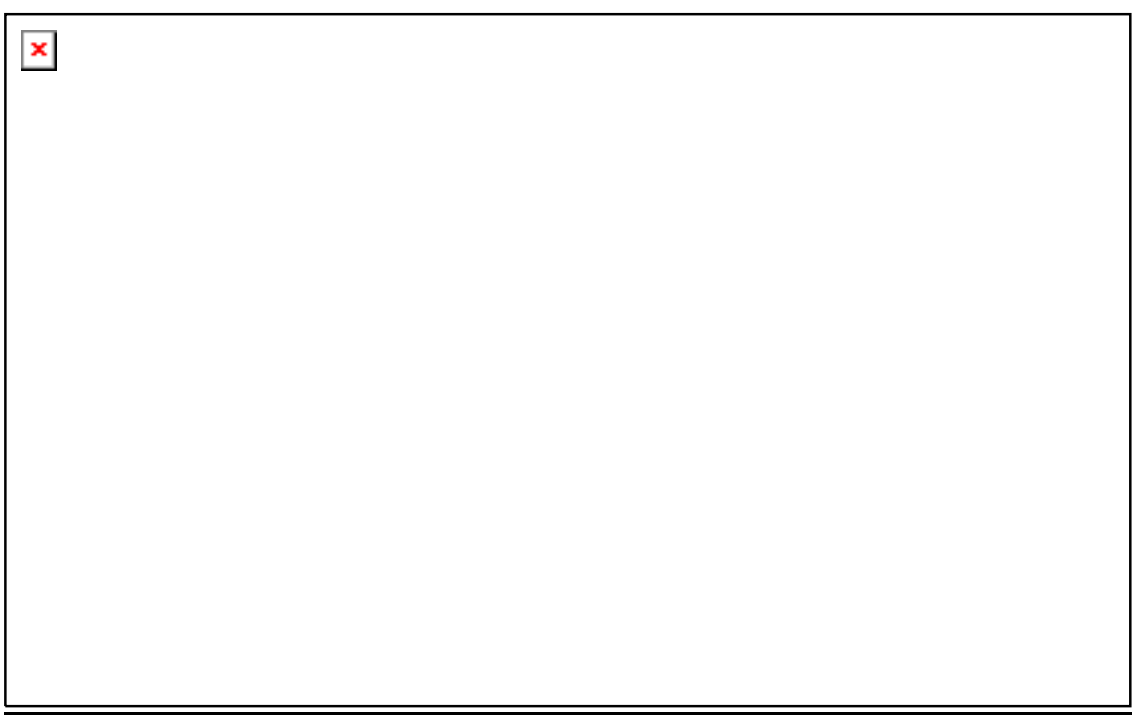

